\title{
Pengaruh Jumlah Anggota, Size, Likuiditas, dan Rentabilitas Koperasi Terhadap Permintaan Jasa Audit Eksternal
}

\author{
Fikri Rizki Utama ${ }^{1}$ \\ ${ }^{1}$ Sekolah Tinggi Ilmu Ekonomi Al-Madani, Kota Bandar Lampung \\ email:"fikriu26@gmail.com
}

\begin{abstract}
The purpose of this research is to empirically examine the influence of the number of members of the cooperative, size, liquidity, and rentability of cooperatives to demand external audit services. This study uses a sample of Cooperative Employees (Kopkar) in the city of Bandar Lampung during 2009-2011 using purposive sampling method. The analysis in this study uses logistic regression equation. The result of this study found that the size variable has a significant influence on the demand for external audit services. While the variable of a number of cooperative members, liquidity, and rentability do not significantly influence the demand for external audit services.
\end{abstract}

Keywords: Request for External Audit Services, Cooperative of Employees, Number of cooperative members, Size, Liquidity, and Rentability.

\section{PENDAHULUAN}

Laporan keuangan merupakan suatu penyajian data keuangan termasuk catatan yang menyertainya, bila ada, yang dimaksud untuk mengkomunikasikan sumberdaya ekonomi (aktiva) dan/atau kewajiban suatu entitas pada saat tertentu atau perubahan atas aktiva dan/atau kewajiban selama suatu periode tertentu sesuai dengan prinsip akuntansi yang berlaku umum atau basis akuntansi komprehensif selain prinsip akuntansi yang berlaku umum (Agoes, 2004). Selain itu juga, laporan keuangan ini menggambarkan indikator kesuksesan suatu perusahaan dalam mencapai tujuan.

Alfurkaniati (2004) mengatakan bahwa laporan keuangan akan bermanfaat jika memenuhi tujuan kualitatif yaitu relevan, dapat dimengerti, daya uji, netral, tepat waktu, daya banding dan lengkap. Selain itu untuk dapat digunakan sebagai salah satu alat untuk pengambilan keputusan laporan keuangan harus dapat dipercaya (reliable). Oleh karena itu, agar laporan keuangan menjadi relevan dan reliable perlu diaudit oleh akuntan publik. Akuntan publik adalah akuntan yang memiliki izin dari menteri keuangan atau pejabat yang berwenang lainnya untuk menjalankan praktik akuntan publik. Yang dimaksud praktik akuntan publik adalah pemberi jasa professional kepada klien yang dilakukan oleh anggota IAI-KAP yang dapat berupa jasa audit, jasa atestasi, jasa akuntansi dan review, perpajakan, perencanaan keuangan perorangan, jasa pendukung litigasi, dan jasa lainnya yang diatur dalam Standar Profesional Akuntan Publik (Agoes, 2004). Tujuan audit laporan keuangan adalah untuk menyatakan pendapat atas kewajaran, dalam semua hal yang material, posisi keuangan dan hasil usaha serta arus kas sesuai dengan prinsip akuntansi yang berlaku umum (Standar Profesional Akuntan Publik, 2001).

Kell, Boynton dan Ziegler (2001) menjelaskan bahwa kebutuhan akan independent audit atau external 
audit atas laporan keuangan disebabkan adanya 4 (empat) kondisi, yaitu: perbedaan kepentingan (conflict of interest), konsekuensi (consequence), kompleknya masalah dan usaha (complexity), dan untuk pengendalian (remoteneses). Pemakai laporan keuangan mungkin mempunyai kepentingan yang berbeda satu sama lainnya. Agar laporan keuangan tersebut dapat dipercaya oleh setiap pemakai, maka data yang disajikan haruslah netral. Holt dan Moizer (1990) menyimpulkan bahwa informasi akuntansi yang disajikan dikatakan wajar bila informasi tersebut dapat dipercaya, bermanfaat, sesuai aturan perusahaan dan praktek akuntansi yang berlaku (Standar Akuntansi Keuangan) tidak berisi penyimpangan maupun kesalahan yang disengaja dan lainnya yang material. Kell, Boynton dan Ziegler (2001) menjelaskan bahwa laporan keuangan yang diaudit mempunyai dampak yang cukup menguntungkan bagi efisiensi dan integritas karyawan. Karena apa yang dikerjakan dan dilaporkan oleh karyawan selama ini masih belum teruji keakuratan dan kewajarannya. Laporan yang diaudit akan memberi hasil paling tidak dalam memperbaiki kesalahan proses akuntansi dan mengurangi kemungkinan kesalahan penilaian aset oleh karyawan. Dampak lain bagi manajemen adalah berdasarkan pemeriksaan tersebut audit eksternal dapat memberikan semacam sugesti untuk memperbaiki pengendalian dan mencapai efisiensi operasi yang lebih besar. Tumbuhnya permintaan terhadap jasa audit pada koperasi ditentukan oleh perkembangan usaha koperasi. Apresiasi masyarakat koperasi terhadap jasa audit menurut Wahyudi (1995) dikelompokkan menjadi 3, yaitu (1) koperasi yang sudah mengenal audit, (2) koperasi yang mulai mengenal audit dan (3) koperasi yang belum mengerti benar manfaat audit. Manfaat yang dapat diberikan oleh audit eksternal hanya akan dapat dipahami dan dimengerti oleh manajemen jika manajemen tersebut mempunyai persepsi yang baik terhadap audit eksternal.

Koperasi yang ada di kota Bandar Lampung berkisar 711 koperasi. Adapun jenis koperasi yang ada meliputi Koperasi Unit Desa (KUD), Koperasi Produsen Tahu Tempe (Kopti), Koperasi Mahasiswa (Kopma), Koperasi Pegawai Republik Indonesia (KPRI), Koperasi Karyawan (Kopkar) dan masih banyak lagi jenis koperasi lainnya. Dari jumlah tersebut, 114 adalah koperasi dengan jenis Koperasi Karyawan (Kopkar). Dalam penelitian ini yang akan dijadikan sampel adalah Kopkar dengan alasan bahwa koperasi tersebut berada di perkotaan dan pengurusnya rata-rata mempunyai pendidikan yang cukup sehingga diharapkan mereka telah mengerti manfaat audit dan menggunakan jasa audit eksternal. Mengingat masih banyaknya koperasi-koperasi saat ini yang belum menyadari manfaat dari pada jasa audit eksternal yaitu dapat memberikan manfaat bagi pemecahan masalah pembangunan, memberikan masukan kepada anggota, badan pegawas, pengurus serta manajer koperasi tentang manfaat ekonomis yang dapat diperoleh bila laporan keuangan diaudit, terutama di dalam meningkatkan kredibilitas laporan keuangan melalui permintaan jasa audit eksternal. Oleh karena itu merupakan hal menarik untuk mengadakan penelitian tentang “Pengaruh Jumlah anggota, Size, Likuiditas, dan Rentabilitas Koperasi terhadap Permintaan Jasa Audit Eksternal.

Tujuan Penelitian ini sendiri adalah untuk memperoleh bukti empiris bahwa jumlah anggota, size, likuiditas, dan rentabilitas koperasi berpengaruh terhadap terhadap permintaan jasa audit eksternal. Sedangkan manfaat yang bisa diambil dari penelitian ini antara lain: hasil penelitian ini diharapkan dapat memberikan saran atau sumber informasi bagi pengurus koperasi karyawan mengenai pengaruh jumlah anggota koperasi, size, likuiditas, dan rentabilitas koperasi terhadap permintaan jasa audit eksternal. Sehingga dapat mengupayakan

Jurnal Akuntansi Indonesia

126 ISSN: 0216-6747; E-ISSN: 2655-9552

Vol. 8 No. 2 Juli 2019 
jalan keluarnya serta dapat digunakan sebagai bahan pertimbangan dan pengambilan keputusan dimasa yang akan datang.

\section{Teori Agensi}

\section{TELAAH LITERATUR DAN PENGEMBANGAN HIPOTESIS}

Konflik kepentingan antara penyaji dan pengguna informasi akuntansi dapat timbul dalam koperasi. Agency theory merupakan suatu masalah resiko moral (moral hazard) dalam hubungan pemilik (pemegang saham) dengan manajer yang memungkinkan timbulnya agency cost. Sesuai konsep Agency theory yang dikemukakan Jensen dan Meckling (1976), adanya hubungan kontrak antara dua pihak yaitu principal (pemilik) dan Agent (pengelola). Principal mendelegasikan beberapa wewenang pengambilan keputusan kepada agen dan masing-masing berusaha memaksimalkan keuntungan. Agency theory memfokuskan pada bentuk penilaian kinerja dan penghargaan yang akan mendorong bawahan bertindak sesuai tujuan perusahaan.

Menurut Arens dan Loebbecke (1996), dengan kondisi masyarakat yang semakin kompleks, terdapat kemungkinan bahwa para pengambil keputusan akan memperoleh informasi yang tidak dapat dipercaya dan tidak dapat diandalkan. Hal ini disebabkan oleh beberapa hal berikut:

1. Hubungan pemberi dan penerima informasi yang tidak dekat.

2 Sikap memihak dan motif lain yang melatarbelakangi penyaji informasi.

3. Data yang berlebihan dan transaksi pertukaran yang kompleks.

Ada tiga cara untuk menanggulangi risiko informasi, yaitu verifikasi informasi oleh pemakai, pemakai menanggung resiko informasi bersama-sama dengan manajemen, atau dilakukan audit atas laporan keuangan (Arens dan Loebbecke, 1996). Audit atas laporan keuangan ini harus dilakukan oleh pihak yang independen dan yang berkompeten, yaitu akuntan publik.

Salah satu kelemahan yang masih membudaya di koperasi adalah kurangnya kesadaran untuk membuat laporan keuangan secara periodik (triwulan, semester). Pada umumnya laporan keuangan disusun hanya sekali dalam setahun, sudah barang tentu jika laporan keuangan disajikan terlambat maka informasi yang disajikan tidak akan bermanfaat lagi untuk pengambilan keputusan.

\section{Permintaan Jasa Audit Eksternal}

Suatu mekanisme untuk meningkatkan keandalan fungsi laporan keuangan dan untuk menghindari konflik antara pemakai dan pembuat laporan keuangan dapat diatasi dengan menggunakan jasa audit eksternal (Akuntan Publik). Untuk melakukan pemeriksaan atas kewajaran laporan keuangan yang disajikan oleh pihak manajemen tersebut. Menurut Mulyadi dan Kanaka (1998), auditing adalah suatu proses sistematik untuk memperoleh dan mengevaluasi bukti secara objektif mengenai peryataan-pernyataan tentang kegiatan dan kejadian ekonomi, dengan tujuan untuk menetapkan tingkat kesesuaian antara peryataan-pernyataan tersebut dengan kriteria yang telah ditetapkan, serta penyampaian hasil-hasilnya kepada pemakai yang berkepentingan. Satu sarana untuk mengatasi konflik antara pemakai dengan penyusun laporan keuangan mengenai keandalan laporan keuangan adalah dengan menggunakan jasa audit eksternal, untuk mengaudit 
laporan keuangan yang disusun oleh manajemen.

Salah satu bentuk pertanggungjawaban agen adalah laporan keuangan yang telah diaudit oleh akuntan publik, yang digunakan sebagai pengontrol pengeluaran agen. Penjelasan di atas merupakan indikasi jasa audit eksternal akan selalu dibutuhkan untuk mengurangi kecurigaan pihak principal kepada pihak pengelola. Undang-Undang Republik Indonesia No. 17 Tahun 2012 tentang perkoperasian pasal 40 ayat 1 menyatakan bahwa laporan keuangan koperasi harus diaudit oleh akuntan publik apabila diminta oleh menteri atau rapat anggota menghendakinya. Kewajiban audit berlaku bagi koperasi besar yang volume penjualannya minimal Rp.1.000.000.000 sesuai Keputusan Menteri Koperasi, Pengusaha Kecil dan Menengah No. 351 /KEP/M/XII/ 1998. Jika dilihat dari manfaat audit bagi suatu badan usaha, diharapkan semua badan usaha koperasi diaudit oleh auditor eksternal, namun dalam kenyataannya tidak semua koperasi diaudit oleh auditor eksternal. Banyak sekali manfaat audit yang dapat dirasakan oleh koperasi, baik itu untuk efisiensi dan integritas karyawan, memperbaiki pengendalian dan efisiensi operasi. Selain itu dengan audit laporan keuangan juga dapat meningkatkan kredibilitas laporan keuangan tersebut. Hal tersebut mengakibatkan semua badan usaha koperasi bersedia melakukan audit secara sukarela (Ardiansah, 2009).

\section{Jumlah Anggota Koperasi}

Jumlah anggota koperasi diprediksi mempengaruhi permintaan jasa audit eksternal karena di dalam koperasi semakin banyak anggota, semakin banyak suara (1 anggota = 1 suara). Sehingga banyaknya suara atau pendapat menyebabkan wawasan dan kepentingan masing-masing berbeda. Atas dasar perbedaan itulah peran dari jasa audit eksternal (Akuntan Publik) diperlukan guna menengahi adanya perbedaan kepentingan (Januarti, 1998).

\section{Size (Besaran Koperasi)}

Januarti (1998) mengatakan bahwa size (besaran koperasi) mencerminkan usaha yang dikelola menjadi besar akan mempunyai potensi untuk menjadi sangat komplek dengan berbagai permasalahan yang ada. Besaran (size) koperasi yang dimaksud dalam penelitian ini adalah ukuran besar kecilnya koperasi.

Sesuai dengan Keputusan Menteri Koperasi Pengusaha Kecil dan Menengah No. 351 /KEP/M/XI I/ 1998 bahwa skala koperasi didasarkan pada volume penjualan yaitu, koperasi dengan volume penjualan kurang dari 500 juta termasuk koperasi kecil, koperasi dengan volume penjualan antara 500 juta sampai dengan I milyar termasuk koperasi menengah dan koperasi yang volume penjualan di atas 1 milyar termasuk koperasi besar. Oleh sebab itu untuk memecahkan masalah yang timbul akibat kompleksnya transaksi yang ada sangat dibutuhkan jasa audit eksternal agar laporan yang disajikan menjadi lebih valid.

\section{Likuiditas}

Likuiditas merupakan suatu rasio indikator mengenai kemampuan perusahaan untuk membayar kewajiban finansial jangka pendek pada saat jatuh tempo dengan menggunakan aktiva lancar yang tersedia. Likuiditas tidak hannya berkenaan dengan keadaan keseluruhan keuangan perusahaan, tetapi juga berkaitan 
dengan kemampuan untuk mengubah aktiva lancar tertentu menjadi uang kas (Alfurkaniati, 2004).

Perusahaan-perusahaan yang rasio likuiditasnya rendah tentunya sangat membutuhkan dana untuk menjalankan operasi jangka pendeknya. Salah satu sumber dana adalah bank atau lembaga keuangan lain. Agar dapat meyakinkan pihak kreditor bahwa secara keseluruhan perusahaan mereka sanggup membayar hutang-hutangnya, maka perusahaan kecil yang memiliki likuiditas yang rendah akan terdorong untuk meminta laporan keuangan mereka diaudit oleh akuntan publik (Ardiansah, 2009).

\section{Rentabilitas}

Munawir (2002) menyatakan rasio rentabilitas adalah rasio yang menunjukkan kemampuan perusahaan untuk menghasilkan laba. la juga berpendapat bahwa suatu perusahaan yang rendabel, maka perusahaan tersebut pada umumnya akan dapat beroperasi secara stabil pula dan dimungkinkan tidak akan mengalami kesulitan keuangan jangka pendek. Menurut Amidipraja dan Wirasasmita (1990), meskipun koperasi tujuannya bukan mengejar untung yang sebesar-besarnya, tetapi pengetahuan keadaan laba koperasi perlu diketahui. Mundur majunya koperasi ditentukan juga adanya rugi dan laba usaha koperasi. Kemampuan koperasi dalam menghasilkan SHU (sisa hasil usaha) dilihat dari rasio rentabilitas dengan menggunakan beberapa rasio seperti rasio laba bersih (net profit margin), rasio operasional (operating margin ratio), rasio rentabilitas modal sendiri (return on equity), dan tingkat pengembalian investasi (return on investment).

\section{Perumusan Hipotesis}

\section{Pengaruh Jumlah anggota koperasi terhadap Permintaan Jasa Audit Eksternal}

Aryanti (2003) mengatakan bahwa keberhasilan koperasi mencakup tiga hal, yaitu business success (keberhasilan di bidang usaha), member success (keberhasilan di bidang anggota) serta development success (keberhasilan dibidang pertumbuhan). Ardiansah (2009) menambahkan bahwa keberhasilan di bidang anggota dapat dilihat dari perkembangan jumlah anggota. Jumlah anggota koperasi yang semakin besar menandakan bahwa koperasi tersebut berhasil menarik masyarakat untuk menjadi anggotanya. Keanggotaan koperasi bersifat sukarela dan didasarkan atas kepentingan bersama sebagai pelaku ekonomi. Permintaan jasa audit mungkin saja datang dari anggota koperasi yang berawal dari adanya asimetri informasi, tentunya akan terjadi antara anggota koperasi yang bukan pengurus koperasi dengan anggota koperasi yang menjadi pengurus koperasi. Untuk mengatasi asimetri informasi ini salah satu cara adalah dilakukannya audit atas laporan keuangan.

Penelitian tentang pengaruh jumlah anggota koperasi terhadap permintaan jasa audit eksternal telah dilakukan oleh Istomo (2002) yang menyatakan permintaan jasa audit eksternal tidak terkait karakteristik jumlah anggota koperasi. Hal tersebut dikarenakan Istomo tidak menggolongkan koperasi yang diteliti berdasarkan jumlah anggota koperasi. Berdasarkan penjelasan di atas, hipotesis alternatif penelitian ini adalah:

$\mathrm{H} 1$ : Jumlah anggota koperasi berpengaruh positif terhadap permintaan jasa audit eksternal 


\section{Pengaruh Size terhadap Permintaan Jasa Audit Eksternal}

Penelitian Chow (1982) dilakukan di Amerika Serikat dengan mengambil sampel perusahaan di NYSE dan OCC. Chow (1982) berpendapat bahwa untuk kepemilikan saham manajerial dan rasio utang/ekuitas, total nilai kepemilikan saham potensial meningkat sejalan dengan meningkatnya ukuran perusahaan. Hal ini menunjukkan bahwa keuntungan dalam memonitoring dan mengikat perjanjian dengan agen secara positif berhubungan dengan ukuran perusahaan. Pada sisi biaya, diprediksi bahwa beberapa biaya dalam menciptakan system monitoring/bonding (mengikat) cenderung tetap. Bahkan untuk perusahaan kecil, mungkin memerlukan sumber daya untuk auditor eksternal menjadi lebih familiar dengan operasi perusahaan. Sekali system monitoring/bonding telah tercipta, biaya marginal untuk operasi cenderung menurun dengan besaran perusahaan (tidak perlu mengambil biaya variabel dua kali unrtuk perusahaan yang dua kali lebih besar).

Kepemilikan saham manajerial dan rasio utang atau ekuitas, total nilai kepemilikan saham potensial meningkat sejalan dengan meningkatnya ukuran perusahaan. Perusahaan yang makin berkembang akan cenderung untuk melakukan pemisahan antara pemilik dan pengelola. Pemisahan ini akan menimbulkan konflik kepentingan antara pemilik (principal) dengan manajer (agent) sebagai mana dikatakan oleh Jones \& Butler (1992), bahwa pemisahan antara pemilik dan manajer sebagai akibat perusahaan berkembang, menyebabkan bertambahnya resiko yang tidak dikehendaki. Sehingga diperlukan laporan keuangan diuji oleh auditor eksternal yang kompeten dan ahli dalam memahami entitas perusahaan, transaksinya dan sistem akuntansinya. Berdasarkan penjelasan di atas, hipotesis alternatif penelitian ini adalah:

H2: Size berpengaruh positif terhadap permintaan jasa audit eksternal

\section{Pengaruh Likuiditas terhadap Permintaan Jasa Audit Eksternal}

Likuiditas tidak hanya berkenaan dengan keadaan keseluruhan keuangan perusahaan, tetapi juga berkaitan dengan kemampuan untuk mengubah aktiva lancar tertentu menjadi uang kas. Perusahaanperusahaan yang rasio likuiditasnya rendah tentunya sangat membutuhkan dana untuk menjalankan operasi jangka pendeknya. Salah satu sumber dana adalah bank atau lembaga keuangan lain. Agar dapat meyakinkan pihak kreditor bahwa secara keseluruhan perusahaan mereka sanggup membayar hutang-hutangnya, maka perusahaan kecil yang memiliki likuiditas yang rendah akan terdorong untuk meminta laporan keuangan mereka diaudit oleh akuntan publik (Ardiansah, 2009).

Penelitian Ardiansah (2009) menunjukkan bahwa sernakin besar rasio likuiditas suatu koperasi, semakin tinggi kemungkinan koperasi secara sukarela menggunakan audit eksternal. Penelitian tentang pengaruh rasio likuiditas terhadap permintaan jasa audit eksternal juga dilakukan oleh Tauringana \& Clark (2000). Berdasarkan penjelasan di atas, hipotesis alternatif penelitian ini adalah:

H3: Likuiditas berpengaruh positif terhadap permintaan jasa audit eksternal

\section{Pengaruh Rentabilitas terhadap Permintaan Jasa Audit Eksternal}

Menurut Amidipraja dan Wirasasmita (1990), meskipun koperasi tujuannya bukan mengejar untung yang sebesar-besarnya, tetapi pengetahuan keadaan laba koperasi perlu diketahui. Mundur majunya koperasi 
ditentukan juga adanya rugi dan laba usaha koperasi. Kemampuan koperasi dalam menghasilkan SHU dilihat dari rasio rentabilitas. Mulyadi (2001) berpendapat bahwa setiap perusahaan yang bermotif mencari laba maupun yang tidak bermotif laba, manajemen selalu berusaha agar organisasi dapat menghasilkan laba (untuk perusahaan bermotif laba) atau sisa hasil usaha (untuk perusahaan yang tidak bermotif laba).

Adanya laba atau sisa hasil usaha tersebut, perusahaan akan memiliki kemampuan untuk berkembang dan tetap mampu mempertahankan eksistensinya sebagai suatu sistem di masa yang akan datang. Berdasarkan penjelasan di atas, hipotesis alternatif penelitian ini adalah:

H4: Rentabilitas berpengaruh positif terhadap permintaan jasa audit eksternal

\section{METODE PENELITIAN}

\section{Desain Penelitian}

Ditinjau dari sifatnya, penelitian ini adalah penelitian kuantitatif, yaitu data yang disajikan berupa angka. Data yang digunakan dalam penelitian ini adalah data sekunder. Data sekunder yang diperlukan dalam penelitian ini adalah laporan keuangan responden tahun 2009-2011 dan data perkembangan Koperasi Karyawan (Kopkar) di Kota Bandar Lampung dari Dinas Koperasi, UKM, dan Perindag kota Bandar Lampung. Teknik pengumpulan datanya adalah dengan meminta laporan keuangan yang sudah masuk ke dinas koperasi dan dengan melakukan contact person dengan manajer atau pengurus koperasi yang menjadi responden

\section{Populasi dan Sampel}

Populasi yang akan digunakan dalam penelitian ini adalah Koperasi Karyawan (Kopkar) di kota Bandar Lampung. Metode penetapan sampel yang digunakan adalah Purposive Sampling, yaitu dimana elemenelemen yang dimasukkan dalam sampel dilakukan dengan sengaja, dengan alasan bahwa sampel tersebut memenuhi kriteria tertentu dan mewakili populasi (Alfurkaniati, 2004). Sampel yang berhasil dikumpulkan berasal dari yang sudah melakukan RAT sampai dengan 2011 yakni sebanyak 31 koperasi (penentuan populasi dan sampel disajikan pada tabel 1). Namun karena periode pengamatan dalam penelitian ini dilakukan selama tiga tahun, yaitu pada periode 2009-2011. Maka jumlah 31 sampel dalam penelitian ini dikali 3 sehingga didapat 93 pengamatan.

\section{HASIL DAN PEMBAHASAN}

\section{Analisis Diskriptif}

Analisis statistik deskriptif dari setiap variabel dapat dijelaskan sebagaimana dalam tabel 3 sebagai berikut:

Untuk koperasi auditan jumlah anggota koperasi terkecil Ln3,89 sedangkan koperasi yang tidak diaudit jumlah anggota koperasi terkecil Ln 3,04. Jumlah anggota koperasi terbesar untuk koperasi auditan Ln 7,20, dan untuk koperasi yang tidak diaudit jumlah anggota koperasinya Ln6,84. Rata-rata (mean) jumlah anggota koperasi untuk koperasi auditan adalah Ln5,5018, rata-rata anggota koperasi yang tidak diaudit adalah Ln 
5,0470. Ini berarti rata-rata anggota koperasi auditan lebih besar dari rata-rata anggota koperasi yang tidak diaudit. Hal ini konsisten dengan teori yang dibangun, yaitu semakin besar jumlah anggota koperasi koperasi maka semakin tinggi permintaan jasa audit eksternal. Standar deviasi jumlah anggota koperasi untuk koperasi auditan adalah Ln0,80085, standar deviasi anggota koperasi yang tidak diaudit adalah $\operatorname{Ln} 1,02128$. Artinya nilai sebaran data jumlah anggota koperasi bervariasi sebab nilai standar deviasinya di atas 0 .

Untuk koperasi auditan volume penjualan terkecil Ln17,72 sedangkan koperasi yang tidak diaudit volume penjualan terkecilnya Ln14,46. Volume penjualan terbesar untuk koperasi auditan Ln24,35 dan untuk koperasi yang tidak diaudit volume penjualannya Ln22,51. Rata-rata (mean) volume penjualan untuk koperasi auditan adalah Ln21,5, rata-rata volume penjualan yang tidak diaudit adalah Ln19,5. Ini berarti ratarata volume penjualan auditan lebih besar dari rata-rata volume penjualan koperasi yang tidak diaudit. Hal ini konsisten dengan teori yang dibangun, yaitu semakin besar volume penjualan (size) koperasi maka semakin tinggi permintaan jasa audit eksternal. Standar deviasi volume penjualan untuk koperasi auditan adalah Ln1,54, standar deviasi volume penjualan koperasi yang tidak diaudit adalah Ln1,797. Artinya nilai sebaran data volume penjualan bervariasi sebab nilai standar deviasinya lebih besar dari 0 .

Untuk koperasi auditan likuiditas terkecil 0,02 sedangkan koperasi yang tidak diaudit likuiditas terkecilnya 0,90 . Likuiditas terbesar untuk koperasi auditan 41,54 dan untuk koperasi yang tidak diaudit likuiditasnya 393,04. Rata-rata (mean) likuiditas untuk koperasi auditan adalah 5,1778 sedangkan rata-rata likuiditas yang tidak diaudit adalah 38,4671. Ini berarti rata-rata likuiditas auditan lebih rendah dari rata-rata likuiditas koperasi yang tidak diaudit. Hal ini konsisten dengan teori yang dibangun, yaitu semakin rendah likuiditas koperasi maka semakin tinggi permintaan jasa audit eksternal. Standar deviasi likuiditas untuk koperasi auditan adalah 7,39 dan standar deviasi likuiditas koperasi yang tidak diaudit adalah 90,49. Artinya nilai sebaran data likuiditas bervariasi sebab nilai standar deviasinya lebih besar dari 0 .

Untuk koperasi auditan rentabilitas terkecil 0,01 sedangkan koperasi yang tidak diaudit rentabilitas terkecilnya -0,09. Rentabilitas terbesar untuk koperasi auditan 0,26 dan untuk koperasi yang tidak diaudit rentabilitasnya 0,23. Rata-rata (mean) rentabilitas untuk koperasi auditan adalah 0,0919 sedangkan rata-rata rentabilitas yang tidak diaudit adalah 0,0907. Ini berarti rata-rata rentabilitas auditan lebih tinggi dari ratarata rentabilitas koperasi yang tidak diaudit. Hal ini konsisten dengan teori yang dibangun, yaitu semakin tinggi rentabilitas koperasi maka semakin tinggi permintaan jasa audit eksternal. Standar deviasi rentabilitas untuk koperasi auditan adalah 0,06599, standar deviasi rentabilitas koperasi yang tidak diaudit adalah 0,07520. Artinya nilai sebaran data rentabilitas bervariasi sebab nilai standar deviasinya lebih besar dari 0 .

\section{Model Regresi}

Berdasarkan hasil regresi Logistik pada tabel 4 dapat dibentuk persamaan sebagai berikut:

$$
Y(1,0)=-17,01+0,00 \mathrm{JA}+0,90 \mathrm{LnSz}-0,002 \mathrm{Lk}-10,16 \mathrm{Rn}
$$




\section{Hasil dan Pembahasan}

\section{Pengaruh Jumlah Anggota Koperasi terhadap Permintaan Jasa Audit Eksternal}

Hasil pengujian menunjukkan bahwa koefisien positif sebesar 0,00 dengan tingkat signifikansi 0,420 pada tingkat signifikansi diatas 5\% (0,05). Artinya tidak ada pengaruh jumlah anggota koperasi terhadap permintaan jasa audit eksternal. Hasil ini tidak mendukung hipotesis bahwa jumlah anggota koperasi berpengaruh positif terhadap permintaan jasa audit eksternal.

Ketidaksesuaian logika teori dan hipotesis dengan hasil penelitian dapat disebabkan kenyataan dilapangan bahwa koperasi yang memiliki jumlah anggota koperasi yang relatif lebih banyak akan memiliki kemampuan yang lebih dalam melakukan pengumpulan modal seperti dari simpanan wajib ketimbang koperasi yang memiliki anggota yang lebih sedikit. Oleh karena itu koperasi tidak begitu membutuhkan dana dari pihak luar yang biasanya mewajibkan atau menganjurkan para calon debitor untuk diaudit oleh akuntan publik. Hasil penelitian ini sejalan dengan penelitian Alfurkaniati (2004).

\section{Pengaruh Size terhadap Permintaan Jasa Audit Koperasi Eksternal}

Hasil pengujian menunjukkan bahwa koefisien positif sebesar 0,90 dengan tingkat signifikansi 0,000 pada tingkat signifikansi dibawah $5 \%(0,05)$. Hasil ini mendukung hipotesis bahwa size berpengaruh positif terhadap permintaan jasa audit eksternal. Alasan size (besaran) koperasi dapat mempengaruhi permintaan jasa audit eksternal adalah karena perusahaan-perusahaan yang makin berkembang maka akan cenderung untuk melakukan pemisahan antara pemilik dan pengelola. Pemisahan ini akan menimbulkan konflik kepentingan antara pemilik (principal) dengan manajer (agent) sebagai mana dikatakan oleh Jones dan Butler (1992) bahwa pemisahan antara pemilik dan manajer sebagai akibat perusahaan berkembang, menyebabkan bertambahnya resiko yang tidak dikehendaki (risk aversion).

Resiko ini bisa berupa alokasi sumber daya perusahaan dengan cara yang tidak konsisten dengan kepentingan pemilik, terutama transfer kekayaan antara pemilik dan manajer. Karena itulah perlu melaporkan laporan keuangan kepada akuntan publik agar mengurangi atau bahkan menyelesaikan konflik kepentingan tersebut. Hasil penelitian ini sejalan dengan penelitian Ardiansyah (2009) dan Alfurkaniati (2004).

\section{Pengaruh Likuiditas terhadap Permintaan Jasa Audit Eksternal}

Hasil pengujian menunjukkan bahwa koefisien negatif sebesar -0,002 dengan tingkat signifikansi 0,174 pada tingkat signifikansi di atas 5\% (0,05). Hasil ini tidak mendukung hipotesis bahwa likuiditas berpengaruh positif terhadap permintaan jasa audit eksternal. Ketidakkonsistenan hasil penelitian dengan logika teori dan hipotesis yang dibangun disebabkan oleh kenyataan dilapangan bahwa koperasi berfungsi sebagai bank bagi anggotanya, anggota bisa meminjam dan menyimpan uangnya dikoperasi.

Seperti yang dikatakan Alfurkaniati (2004) bahwa simpanan anggota yang tidak tergolong simpanan wajib dan simpanan pokok akan dikelompokkan ke kewajiban jangka pendek baik dalam bentuk simpanan sukarela atau tabungan. Hal ini menyebabkan kewajiban jangka pendek yang ada lebih banyak didapat dari anggota dari pada pihak kreditor sehingga kebutuhan akan dana segar dapat tercukupi dengan baik dari 
simpanan anggotanya. Oleh karena itu koperasi tidak perlu meminta jasa audit eksternal untuk mengaudit laporan keuangannya, guna meyakinkan pihak kreditor bahwa secara keseluruhan koperasi mereka sanggup membayar hutang-hutangnya, sebab sudah tersedianya simpanan anggota. Hasil penelitian ini sejalan dengan penelitian Alfurkaniati (2004)

\section{Pengaruh Rentabilitas terhadap Permintaan Jasa Audit Eksternal}

Hasil pengujian menunjukkan bahwa koefisien negatif sebesar -10,16 dengan tingkat signifikansi 0,028 pada tingkat signifikansi di bawah $5 \%(0,05)$. Hasil ini tidak mendukung hipotesis bahwa rentabilitas berpengaruh positif terhadap permintaan jasa audit eksternal. Ketidaksesuaian logika teori dan hipotesis dengan hasil penelitian dapat terjadi karena bagi anggota koperasi sisa hasil usaha sama dengan transaksi usaha. Jadi besar kecilnya SHU bergantung pada transaksi tiap-tiap anggota kepada koperasinya.

Sebagaimana diketahui bahwa menurut Amidipraja dan Wirasasmita (1990), kemampuan koperasi dalam menghasilkan SHU dilihat dari rasio rentabilitasnya. Meskipun koperasi tujuannya bukan mengejar untung yang sebesar-besarnya, tetapi pengetahuan keadaan laba koperasi perlu diketahui. Mundur majunya koperasi ditentukan juga adanya rugi dan laba usaha koperasi. Hasil penelitian menunjukkan semakin tinggi tingkat rasio rentabilitas justru menurunkan permintaan jasa audit eksternal. Oleh karena itu meningkatnya laba pada suatu koperasi justru membuat pengurus maupun anggota koperasi tidak terlalu membutuhkan jasa akuntan publik, sebab koperasi yang menunjukkan tingkat rasio rentabilitas yang tinggi berarti menghasilkan laba yang tinggi pula, dan dengan laba yang tinggi tersebut tentu saja kegiatan operasional koperasi akan berjalan dengan baik sehingga muncul anggapan bahwa permintaan jasa audit eksternal tidak dibutuhkan.

\section{KESIMPULAN, KETERBTASAN DAN SARAN}

\section{Kesimpulan}

Penelitian ini menggunakan analisis regresi logistik untuk mengetahui apakah jumlah anggota koperasi, size, likuiditas, dan rentabilitas berpengaruh terhadap permintaan jasa audit eksternal. Penelitian ini menggunakan sampel 31 laporan keuangan koperasi karyawan di kota Bandar Lampung selama tahun 20092011.

Permintaan jasa audit eksternal diolah dengan menggunakan metode purposive sampling, dari empat variabel independen yang diuji, hanya satu variabel yang memberikan pengaruh positif signifikan terhadap permintaan jasa audit eksternal. Variabel independen yang berpengaruh positif signifikan adalah size $\left(\mathrm{X}_{2}\right)$. Variabel jumlah anggota koperasi $\left(\mathrm{X}_{1}\right)$ memiliki pengaruh yang tidak signifikan terhadap permintaan jasa audit eksternal dan memiliki arah yang positif. Variabel likuiditas $\left(\mathrm{X}_{3}\right)$ memiliki pengaruh yang tidak signifikan terhadap permintaan jasa audit eksternal dan memiliki arah yang negatif. Variabel rentabilitas $\left(\mathrm{X}_{4}\right)$ memiliki pengaruh yang signifikan terhadap permintaan jasa audit eksternal, tetapi memiliki arah yang negatif.

\section{Keterbatasan Penelitian}

Penelitian ini memiliki beberapa keterbatasan yang memerlukan perbaikan dan pengembangan untuk 
penelitian-penelitian selanjutnya. Keterbatasan-keterbatasan tersebut adalah :

1. Penelitian ini hanya menggunakan Koperasi Karyawan (Kopkar) dalam pengambilan sampel sehingga hasil penelitian ini tidak dapat digeneralisasikan pada jenis koperasi lain seperti Koperasi Unit Desa (KUD), Koperasi Produsen Tahu Tempe (Kopti), Koperasi Mahasiswa (Kopma), atau Koperasi Pegawai Republik Indonesia (KPRI).

2. Penelitian ini hanya meneliti 31 koperasi selama 3 tahun.

\section{Saran}

Penelitian selanjutnya yang dapat disarankan dari penelitian ini yaitu:

Diharapkan pada penelitian selanjutnya memakai sampel pada jenis koperasi lain seperti Koperasi Unit Desa (KUD), Koperasi Produsen Tahu Tempe (Kopti), Koperasi Mahasiswa (Kopma), atau Koperasi Pegawai Republik Indonesia (KPRI).

1. Diharapkan penelitian berikutnya mampu melakukan pengamatan yang lebih panjang dengan jumlah koperasi yang lebih banyak.

2. Diharapkan dalam penelitian selanjutnya, untuk mempertimbangkan variabel-variabel lain yang mungkin berpengaruh terhadap permintaan jasa audit eksternal. Jika dilihat dari peramalan model, ketepatan peramalan model ini hanya 75,27\%. Dengan penambahan variabel lain diharapkan ketepatan peramalan model akan semakin meningkat. 


\section{DAFTAR PUSTAKA}

Agoes, Sukrisno. 2004. Auditing (Pemeriksaan Akuntan) oleh Kantor Akuntan Publik. Jakarta. Lembaga Penerbit Fakultas Ekonomi Universitas Indonesia.

Alfurkaniati, 2004. Analisis Faktor-Faktor Yang Mempengaruhi Permintaan Jasa Audit Akuntan Public Pada Koperasi Perkotaan Di Pekanbaru-Riau. Tesis. Semarang. S2 Program Studi Akuntansi Fakultas Pascasarjana Universitas Diponegoro

Ardiansah, N.M. 2009. Pengaruh Karakteristik Koperasi Terhadap Permintaan Jasa Audit (Studi Empiris Koperasi di Kota Semarang). Jurnal Dinamika Akuntansi.

Arens, Alvin A and James K Loebbecke. 1996. Auditing Pendekatan Terpadu. Edisi Indonesia. Salemba Empat. Jakarta.

Aryanti, A.D. 2003. Analisis Faktor-Faktor yang Mempengaruhi Keputusan Klien Melakukan Pergantian Kantor Akuntan Publik (Survey Beberapa KAP di Surabaya dan Malang). Skripsi. Malang: Fakultas Ekonomi Universitas Brawijaya.

Chow, Chee W.,1982. The Demand for External Auditing: Size, debt and Ownership Influences, Accounting Review.

Holt, G. and Moizer, P. 1990. The meaning of audit reports, Accounting and Business Research, Vol. 20, no. 78, pp. 111-22.

Ikatan Akuntan Indonesia. 2001. Standar Profesi Akuntan publik (Standar Auditing, Standar Atestasi, Satandar Jasa Akuntansi Dan Review). Jakarta. Penerbit Salemba Empat.

Istomo, S.B. 2002. Faktor-Faktor yang Mempengaruhi Permintaan Jasa Eksternal Audit Koperasi Pegawai Republik Indonesia, Studi Kasus Pada 6 (enam) Kabupaten/Kota Jawa Tengah. Tesis Tidak dipublikasikan. Semarang: S2 Program Studi Akuntansi Fakultas Pascasarjana Universitas Diponegoro

Januarti, I. 1997: Permintaan Jasa Audit Pada Koperasi dan Implikasinya terhadap Profesi Akuntan Publik di Eks. Karesidenan Semarang, Laporan Penelitian Universitas Diponegoro.

Jensen, M. C., and Meckling, W. H. (1976). Theory of the Firm: Managerial Behavior, Agency Costs and Ownership Structure. Journal of Financial Economics, 3(4), 305-360.

Jones, G.R. and J.E. Butler. 1992. Managing Internal Corporate Enterpreneurship: an Agency teory Perspective. Journal of Management, Vol. 18 No. 4, 733- 749

Mulyadi, dan Kanaka Puradireja. 1998, Auditing, Edisi Kelima, Salemba Empat, Jakarta.

Mulyadi. 2001. Balanced Scorecard: Alat Manajemen Kontemporer Untuk Pelipatgandaan Kinerja Keuangan Perusahaan. Jakarta. Salemba Empat.

Munawir. 2002. Analisa Laporan Keuangan, Edisi Keempat. Liberty. Yogyakarta.

Republik Indonesia. 2012. Undang-Undang No. 17 Tahun 2012 tentang Perkoperasian. Lembaran Negara Tahun 2012, No 40. Jakarta. Sekretariat Negara.

Tauringana, V. and S. Clark. 2000. Demand for External Auditing: Managerial Share Ownership, Size, Gearing and Liquidity Influences. Management Accounting Journal, Vol. 15 No. 4, 160-168 
Wahyudi. 1995. Implementasi Audit Terhadap Koperasi Suatu Refleksi, Pusat Informasi Perkoperasian, no. 144,th. XIV

Welter G, Kell William, CC. Boyton, Richard Ziegler, 2001: Modern Auditing, 7th, Willey International Edition.

Wirasasmita, R. Amidipraja. 1990. Manajemen Koperasi. Bandung. Pionir Jaya 


\section{LAMPIRAN}

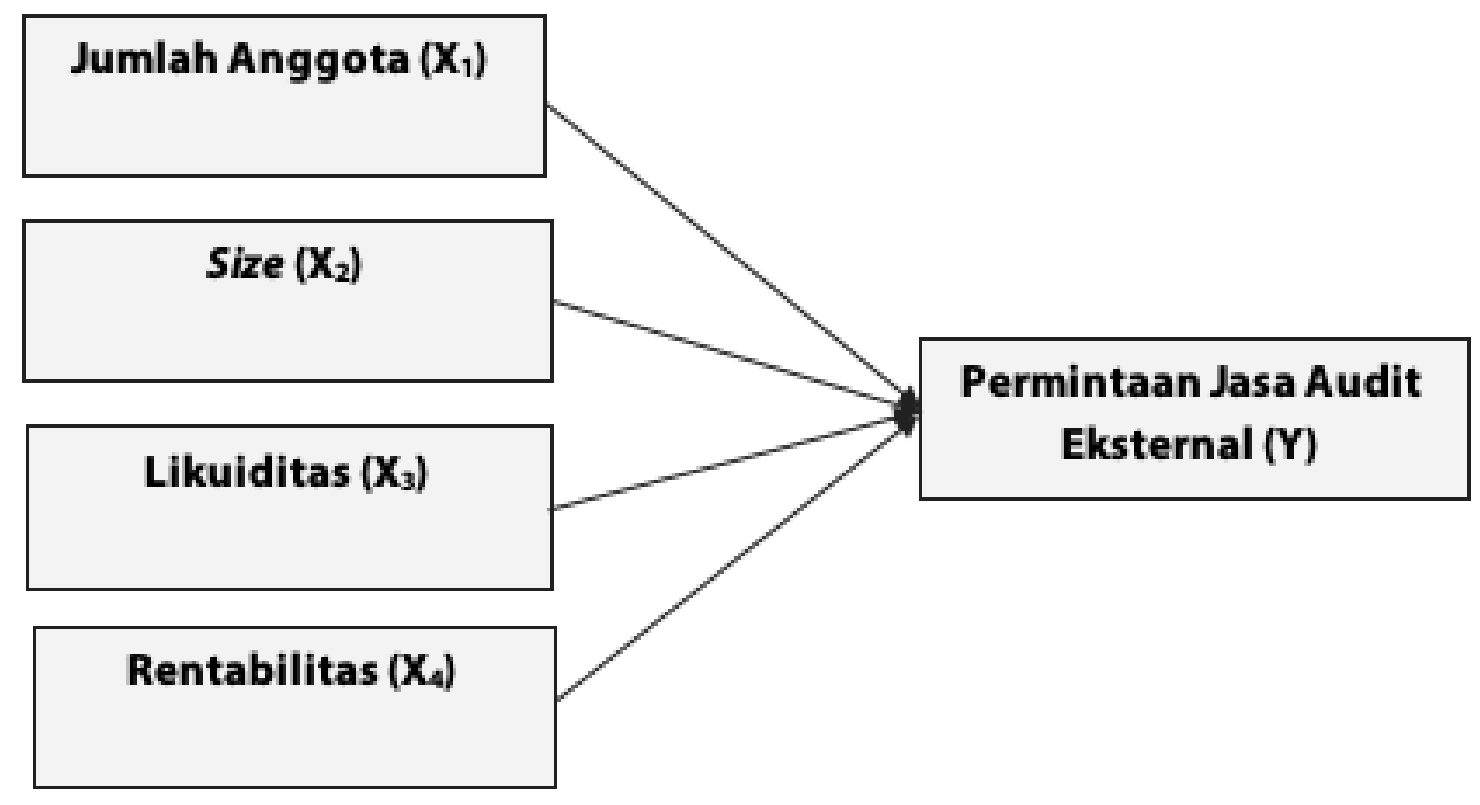

Gambar 1

Kerangka Pemikiran

Tabel 1. Hasil penentuan populasi dan sampel penelitian

\begin{tabular}{lc}
\hline \multicolumn{1}{c}{ Uraian } & Jumlah \\
\hline Koperasi Karyawan yang terdaftar di dinas koperasi & 114 \\
Koperasi yang dikeluarkan karena koperasi tersebut tidak aktif & $(28)$ \\
Sampel yang dikeluarkan karena data yang diperlukan tidak lengkap & 31 \\
Jumlah sampel yang digunakan dalam penelitian
\end{tabular}


Tabel 2. Pengukuran Variabel Penelitian

\begin{tabular}{lll}
\hline Kode & \multicolumn{1}{c}{ Nama Variabel } & Pengukuran \\
\hline PJA & Permintaan Jasa Audit Eksternal & Lap. Keuangan \\
JA & Jumlah Anggota & Jumlah Anggota Koperasi \\
LnSz & Size & Ln Volume Penjualan \\
Lk & Likuiditas & \\
Rt & Rentabilitas & \\
\hline
\end{tabular}

Tabel 3. Statistik Deskriptif Variabel Dependen

\begin{tabular}{lllll}
\hline Variabel & \multicolumn{1}{c}{ Keterangan } & Audit $(\mathrm{N}=45)$ & $\begin{array}{c}\text { Tidak Audit } \\
(\mathrm{N}=48)\end{array}$ & $\begin{array}{c}\text { Keseluruhan } \\
(\mathrm{N}=93)\end{array}$ \\
\hline \multirow{3}{*}{ Jumlah- } & Minimum & 3,89 & 3,04 & 3,04 \\
Anggota- & Maximum & 7,20 & 6,84 & 7,20 \\
Koperasi & Mean & 5,5018 & 5,0470 & 5,2671 \\
Size & Minimum & 0,80085 & 1,02128 & 0,94436 \\
(volume - & Maximum & 17,72 & 14,46 & 14,46 \\
penjualan) & Mean & 21,35 & 22,51 & 24,35 \\
& Std. Deviation & 1,54004 & 1,79780 & 20,4695 \\
& Minimum & 1,02 & 0,90 & 0,94730 \\
Likuiditas & Maximum & 41,54 & 393,04 & 393,04 \\
& Mean & 5,1778 & 38,4671 & 22,3594 \\
& Std. Deviation & 7,39355 & 90,49150 & 67,00203 \\
& Minimum & 0,01 & $-0,09$ & $-0,09$ \\
Rentabilitas & Maximum & 0,26 & 0,23 & 0,26 \\
& Mean & 0,0919 & 0,0907 & 0,0913 \\
& Std. Deviation & 0,06599 & 0,07520 & 0,07051 \\
\hline
\end{tabular}

Pengaruh Jumlah Anggota, Size, Likuiditas, dan Rentabilitas Koperasi 
Tabel 4. Hasil Regresi Logistik

\begin{tabular}{cccc}
\hline Nama Variabel & B & Sig. & Simpulan \\
\hline C & $-17,01$ & 0,000 & \\
JA & 0,00 & 0,420 & $\mathrm{H}_{1}$ tidak terdukung \\
Ln Sz & 0,90 & 0,000 & $\mathrm{H}_{2}$ terdukung \\
Lk & $-0,02$ & 0,132 & $\mathrm{H}_{3}$ tidak terdukung \\
Rn & $-10,16$ & 0,028 & $\mathrm{H}_{4}$ tidak terdukung \\
\hline
\end{tabular}

